\title{
Financial Performance of Islamic and Conventional Banks in Malaysia: A Comparative Analysis
}

\author{
Yasin Ahmed Sulub and
}

Marhanum Che Mohd Salleh

International Islamic University Malaysia

\begin{abstract}
This paper analyses the financial performance of Islamic (IB) and conventional banks (CB) in Malaysia comparatively, within the scope of a dual setting arrangement in the Malaysian financial industry. Performance evaluation of both types of banks relies on ratio analyses which include Return on Equity (ROE), Return on Assets (ROA), Earnings per Share (EPS) and Debt Ratio. Data for this study covers four full-fledged IBs and four CBs in the period between 2012 and 2016. Based on statistical analysis (ttest and correlation analysis), the average of ROE was $6 \%$ for IBs and $14 \%$ for CBs. Results of t-test reveals that this higher performance of CBs is significant (ttest $=1.957, p$-value $=0.029)$. Furthermore, both ROA and EPS were significantly different between the two groups at $p$-value less than $1 \%$. These results indicate that the Malaysian CBs performed better than IBs, at least for the banks included in this study. In terms of debt ratio, (the percentage of liabilities to total assets), IBs carry more debts than CBs. The risk of this higher debt is that the bank may be at risk of bankruptcy and may not be able to pay its obligations on time. The difference between the average debt of the two groups is significant at less than $5 \%$ (t-test $=-2.251, p$ value $=0.015$ ). Therefore, not only is IBs' performance inferior to CBs but their debt ratio is also higher. This research has implications for IBs; they should further improve their performance to become more competitive in the current environment for the financial industry. More importantly, IBs need to uphold Islamic ethics throughout their business operations to ensure that both the stated principles and subsequent objectives are achieved.
\end{abstract}

Keywords: Islamic Banks; Conventional Banks; Financial Performance; Malaysia 


\section{Introduction}

The phenomenal growth of Islamic financial institutions over the past two decades is captivating. According to the Islamic Financial Services Board (2018), the total worth of the Islamic financial services industry slightly surpassed USD2 trillion. IBs and CBs coexist and function in a dual banking system in many countries (Chen et al., 2018; Ibrahim and Rizvi, 2018). With Saudi Arabia and Malaysia being the leading market players, IBs are also emerging in Europe and United States. The uniqueness of IBs originates from the prerequisite of complying with Shariah in all of their activities, including not dealing with interest rates or socially detrimental industries.

The financial crisis that has occurred globally, and even affected countries that have generally followed sound fiscal and monetary policies, has seized up money markets and prompted an abrupt decrease in property and stock values, bank failures and a concern about the future of the global economy and financial systems (Hasan and Dridi, 2011; Ivashina and Scharfstein, 2010; Kayed and Hassan, 2011). The subprime mortgage crisis in the US led to concerns about the liquidity and solvency of the financial system (Ivashina and Scharfstein, 2010). The conventional viewpoint holds that the recent global financial crisis was stimulated by remarkably high liquidity, imprudent loans and the rapid pace of financial engineering, which used nontransparent and intricate instruments for risk transfer (Kayed and Hassan, 2011). Moreover, there was negligence of the lender-borrower relationship and an unbalanced rise in asset prices, particularly in the structured credit instrument market, weak regulatory supervision, poor governance systems, unsound risk management and a structure that motivated unrestrained risk taking, which prompted a financial collision (Ivashina and Scharfstein, 2010). Such a crisis would not have taken place under an Islamic financial system given that most, if not all, of the factors that caused and provoked the expansion of the crisis are prohibited under Islamic law (Kayed and Hassan, 2011).

The stability of IBs amid the recent global financial crisis has attracted the attention of industry practitioners, academics and the general public. This global financial crisis revived interest in the relationship between financial stability and Islamic banking industry during the financial crisis (Hasan and Dridi, 2011).

Consequently, to contribute to the current literature, this paper aims to compare the financial performance of a sample of IBs and CBs in Malaysia. The next section reviews the prior studies chronologically followed by methodology and analysis. Then, the empirical results of the study are discussed and supported with conclusions. Last, the limitations of the paper, which ought to be addressed by future studies, are explained.

\section{Literature Review}

There has been a growing interest in Islamic banking research over the past two decades. Most of the previous studies were performance related research analysing the business model of Islamic banking (Ahmad and Hassan, 2007; Hasan and Dridi, 2011). A growing number of empirical studies compare financial performances of IBs and CBs in many different countries, including Bahrain (Samad, 2004), Malaysia (Kasim

International Journal of Management and Applied Research, 2019, Vol. 6, No. 4 
and Majid, 2010; Wasiuzzaman and Gunasegavan, 2013), Pakistan (Khan et al., 2017) amongst others.

There has been a prominent argument that IBs are more stable than CBs because of Shariah compliance and risk management (Abdullah et al., 2007; Alam et al. 2016; Boo et al., 2017; Hasan and Dridi, 2011). This was particularly evident during and after the 2008-09 global financial crisis (Chapra, 2011). However, earlier research comparing IBs and CBs presented contradictory findings. Samad (2004) investigated the performance of IBs and CBs in Bahrain during the post-Gulf War period (19912001). The study used nine financial ratios to assess profitability, credit and liquidity risks. In this study, six IBs and fifteen CBs were scrutinized. The findings of this study revealed that there is no significant difference in profitability and liquidity between IBs and CBs. However, IBs were found to have less credit risk than CBs. For instance, Khan et al. (2017) concluded that IBs in Pakistan perform relatively better in terms of profitability, efficiency, risk and liquidity management, while CBs are superior in asset quality. Based on a sample of 24 banks (5 Islamic and 19 conventional banks) listed on the Karachi Stock Exchange (KSE) during the period of 2007 and 2014, Khan et al. (2017) evaluated the financial performances of these banks using five financial ratios: profitability, efficiency, risk, asset quality and liquidity. Khan et al. (2017) concluded that IBs outperform CBs due to risk management practices in IBs being superior to CBs.

More recently, however, the Islamic Financial Services Board (2018) reported that the non-performing loan ratio of European Union banks is better than the non-performing financing ratio of Islamic banks, despite IBs outperforming EU banks in terns of return on equity, return on assets and cost-to-income.

A number of empirical studies evaluated the financial performances of IBs and compared them with CBs during, before and after the financial crisis (Abdullah et al., 2007; Alam et al. 2016; Boo et al., 2017; Hasan and Dridi, 2011; Ibrahim and Rizvi, 2018). Alam et al. (2016) found that the performances of both conventional and Islamic unit trusts were almost identical before the global financial crisis; however, Islamic unit trusts performed slightly better than the conventional ones during and after the financial crisis. Similarly, Boo et al. (2017) concluded that Islamic unit trusts outperformed the conventional counterpart, particularly during and after the financial crisis.

Based on a sample of $120 \mathrm{CBs}$ and IBs (about one fourth were IBs) from eight countries collected between 2005 and 2009, Hasan and Dridi (2011) concluded that IBs are more resilient than CBs, using four financial ratios: profitability, credit growth, asset growth and external rating. In a similar vein, Jawadi et al. (2014) showed that the impact of the global economic downturn 2008-2009 on Islamic markets is less significant than on the conventional counterpart, while Ibrahim and Rizvi (2018) found that the lending growth of IBs is resilient to the financial crisis. Contrary to the statistical findings of previous research (Hasan and Dridi, 2011; Jawadi et al., 2014; Ibrahim and Rizvi, 2018), Kasim and Majid (2010) found that both Islamic and conventional banking systems are vulnerable to financial shocks, using the vector

International Journal of Management and Applied Research, 2019, Vol. 6, No. 4 
auto-regression (VAR) method in analysing data collected between 1997 and 2009. The study of Kasim and Majid (2010) is supported by Bourkhis and Nabi (2013). Using a sample of 34 IBs and $34 \mathrm{CBs}$ from 16 countries, regression analysis indicated that there is no significant difference in terms of the effect of the financial crisis on the soundness of IBs and CBs.

Wasiuzzaman and Gunasegavan (2013) compared the performance of IBs and CBs in Malaysia over the period from 2005 to 2009. Examining the profitability, operational efficiency, capital adequacy, asset quality, and capital adequacy, a sample of five IBs and nine $\mathrm{CBs}$ were selected for this study. Economic conditions and corporate governance issues were also incorporated in the analysis. The findings of this study indicated that the return on average asset, board size and bank size of CBs was higher when compared to IBs. Nevertheless, IBs have higher operational efficiency, liquidity, asset quality, board independence and capital adequacy. Remarkable differences between the two types of banks were found for all variables, aside from board independence and profitability.

The study of Yanikkaya et al. (2018) reflects the complicated nature of Islamic banking in that IBs have different profitability dynamics compared to conventional banks. Based on a sample of $74 \mathrm{IBs}$ and $354 \mathrm{CBs}$ in 23 countries for the period between 2007 and 2013, Yanikkaya et al. (2018) measured the performance of the selected banks using the net interest margin and the return on assets. Yanikkaya et al. (2018) found that both financial ratios are not consistent over time, especially for IBs.

Interestingly, Chen et al. (2018) found that asst diversification plays an important role in determining the financial performances of IBs and CBs. Based on data collected between 2006 and 2012 from three countries (Malaysia, Pakistan, and Indonesia), Chen et al. (2018) found that bank size and diversification positively affect the profitability of banks, regardless of bank type (i.e. Islamic or conventional banking).

Table 1 summarizes the findings of selected previous studies available in the literature. In general, while there is no consensus in the literature with respect to the difference between IBs and CBs, it appears that the soundness of IBs in the 2008 financial crisis does not imply that IBs are superior to $\mathrm{CBs}$ in terms of performance. However, literature studies overlook qualitative aspects, such as the impact of the legal system and governance characteristics. Although these dimensions are also not included in this study, the contradictory findings from previous studies regarding different performance levels indicate that it is necessary to carry out further research on this topic.

Table 1: Summary of literature review on financial performance of IBs and CBs

\begin{tabular}{lllll}
\hline Author & Country & $\begin{array}{l}\text { Study } \\
\text { period }\end{array}$ & $\begin{array}{l}\text { Financial ratio/ } \\
\text { Data analysis } \\
\text { method }\end{array}$ & Findings \\
\hline Samad (2004) & Bahrain & $1991-$ & $\begin{array}{l}\text { Profitability, } \\
\text { credit and }\end{array}$ & $\begin{array}{l}\text { No significant difference in } \\
\text { profitability and liquidity }\end{array}$ \\
\hline
\end{tabular}

International Journal of Management and Applied Research, 2019, Vol. 6, No. 4 


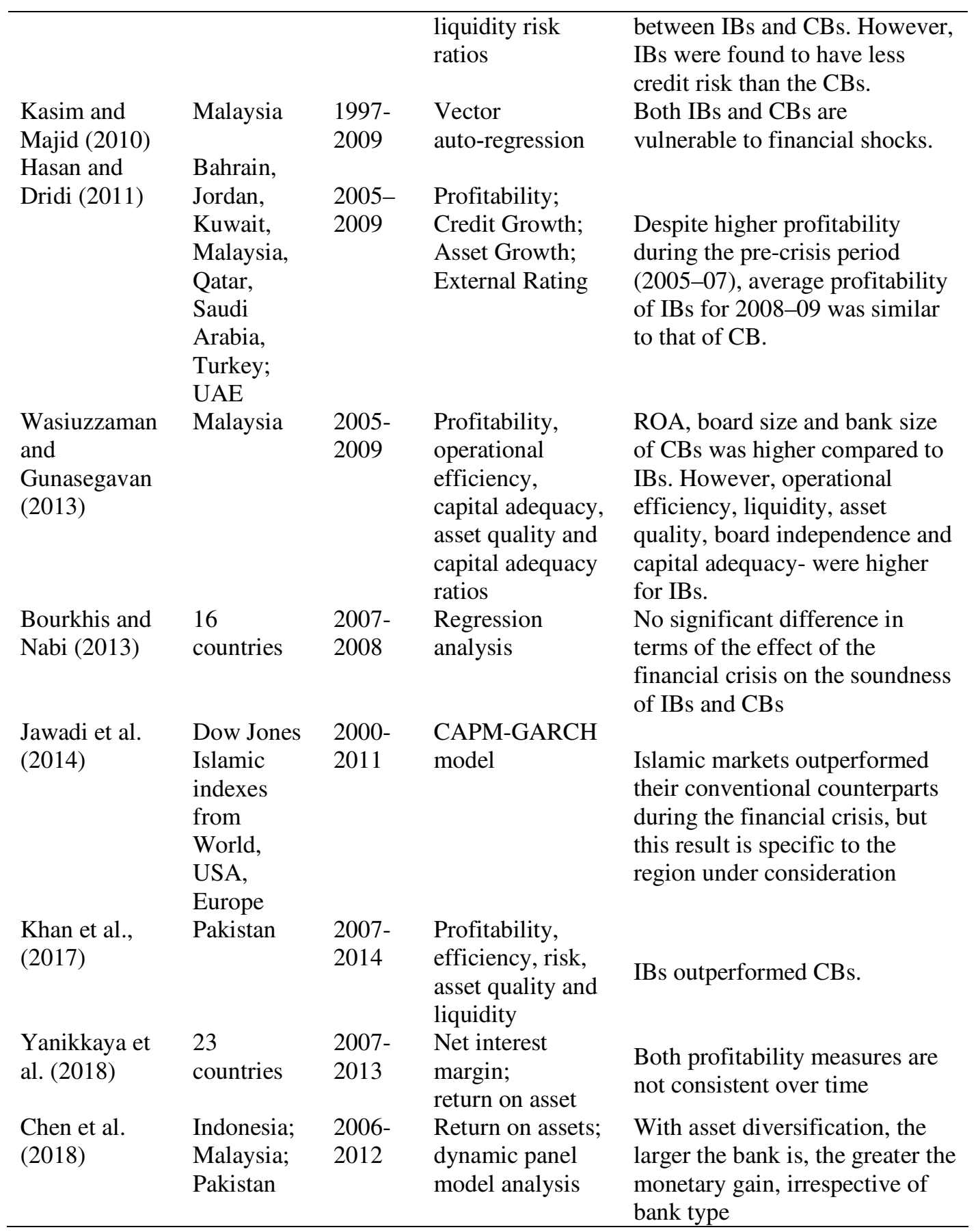

\section{Research Methodology}

This research is structured quantitatively; four full-fledged IBs and four CBs in Malaysia have been chosen. Malaysia is renowned for its status as international Islamic finance hub. Amid the rapid growth of the global Islamic finance industry, Malaysia has been one of the leading countries with Islamic banking assets accounting

International Journal of Management and Applied Research, 2019, Vol. 6, No. 4 
for $9.1 \%$ of the global industry assets in 2018 (Islamic Financial Services Board, 2018).

Secondary data is gathered from the selected banks' annual reports covering the period from 2012 to 2016. While the IBs are chosen based on the full compliance of their operations with Shariah, comparative conventional banks were drawn based on similar characteristics, particularly on similarity of their capital structures (see Table 3). The list of the sample banks reviewed in this research is presented in Table 2.

Table 2: List of full-fledged Islamic and conventional banks

\begin{tabular}{cc}
\hline Islamic banks & Conventional banks \\
\hline Bank Islam Malaysia Berhad & Affin Bank Berhad \\
Bank Muamalat Malaysia Berhad & Citibank Berhad \\
Kuwait Finance House & Ambank Berhad \\
Al Rajhi Bank & CIMB Bank Berhad \\
\hline
\end{tabular}

Accordingly, to evaluate financial performance of the banks, four different financial ratios were adopted in this research. Given that the one of the key objectives of businesses is to maximize shareholders wealth, measures such as Return on Equity (ROE), Return on Assets, Bank Leverage (BL) and Earning per Share (EPS) would reflect the profit generated by the company and hence this approach is chosen to measure the financial performance of the banks. The following are the formulas for these four measures:

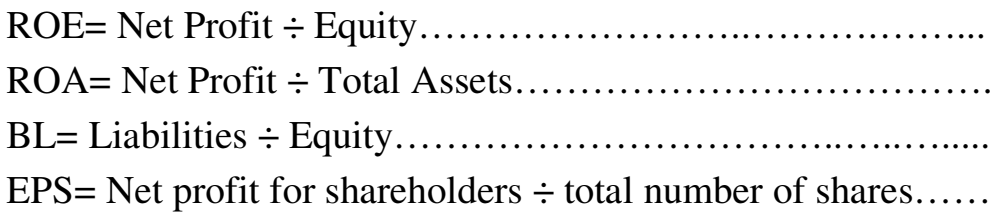

Table 3: Average Values of the banks types included in the sample

\begin{tabular}{lrr}
\hline Average values & Islamic banks & Conventional banks \\
\hline Total Assets & $21,269,546$ & $88,730,558$ \\
Total Liabilities & $19,321,923$ & $78,560,852$ \\
Equity & $1,944,795$ & $10,169,706$ \\
Net Profit & 165,664 & $1,852,765$ \\
Return on Equity & $6 \%$ & $14 \%$ \\
Return on Assets & $0.5 \%$ & $3 \%$ \\
Earnings Per Share (EPS) & 9.416 Cent & 147.06 Cent \\
Debt Ratio (leverage) & 9.329 & 6.864 \\
\hline
\end{tabular}

In terms of data analysis, the following tests were conducted: descriptive analysis, $\mathrm{t}$ test of differences and also a simple correlation analysis between the ratios.

\section{Results}

\section{Descriptive Statistics}

As in Table 3, descriptive analysis was first conducted to explain all variables used in this research. Overall, from year 2012 to 2016, the total assets of the four full-fledged

International Journal of Management and Applied Research, 2019, Vol. 6, No. 4 
IBs under study were quite small (RM 21 Million) compared to the assets of CBs which were RM 88 Million. As the total assets of CBs were quite high, their total liabilities were also representing nearly the same proportion. Having high values of assets and equity, CBs have recorded higher return on asset as well as return on equity figures compared to the IBs (3\% ROA and 14\% ROE respectively). In addition, although the EPS and other performance measures may be dependent on bank size, the substantial difference shows that IBs in the sample performed less effectively than CBs.

\section{Performance Comparison}

As mentioned earlier, to compare the performance of these two categories of banks, four measures have been adopted, which were ROE, ROA, Debt-ratio and EPS. Table 4 shows that the average ROE was $6 \%$ for IBs and $14 \%$ for CBs. Results of t-test reveals that this higher performance of $\mathrm{CBs}$ is significant (t-test $=1.957, p$-value $=$ 0.029). Furthermore, both ROA and EPS were significantly different between these two groups at $p$-value less than $1 \%$. These results mean that CBs perform better than IBs in Malaysia, at least for the sample banks chosen for this study. In terms of debt ratio, which measures the percentage of liabilities to total assets, IBs carry more debts than CBs. The risk of this higher debt is that the bank may be at risk of bankruptcy and may not be able to pay its obligations on time. The difference between the average of debts of the two groups is significant at less than 5\% ( $\mathrm{t}$-test $=-2.251, p$-value $=0.015)$. Therefore, not only are IBs' performance inferior to $\mathrm{CBs}$ but their debt ratio is also higher.

Table 4: t-test for mean differences

\begin{tabular}{lllcc}
\hline Group & ROE & ROA & Debt-ratio & EPS \\
\hline Conventional Banks & 0.1436 & 0.0319 & 6.8648 & 147 cents \\
Islamic Banks & 0.0602 & 0.0054 & 9.3290 & 9.41 cents \\
t-test & $1.9570 *$ & $3.1842^{* *}$ & $-2.2512^{*}$ & $3.2668^{* *}$ \\
$p$-value (Sig.) & 0.0289 & 0.0014 & 0.0151 & 0.0012 \\
\hline
\end{tabular}

Note: $*$ and $* *$ significant at $5 \%$ and $1 \%$, respectively

\section{Test of Correlation}

Table 5 presents a Pearson correlation matrix, which indicates that being an Islamic bank is correlated with higher debt ratio ( $p$-value<0.05). This may be due to the preference of a high number of Muslims in Malaysia for lending their money to Islamic banks (Amin, 2012), thereby facilitating the access of Islamic banks to capital. Moreover, the total assets, return on equity, return on assets and earnings per share were found to be negatively associated with Islamic banks in the sample. This can be interpreted that being an Islamic bank is associated with smaller assets, lower ROA, lower ROE and smaller earnings per share. Furthermore, the results from the Pearson correlation test indicate that return on equity and debt ratios are positively correlated with total assets at a significance level of 5 percent and 1 percent, respectively. This implies that as total assets increase, return on equity and debt ratio would increase and vice versa. This is consistent with the logical notion that bigger banks, in terms of size, have larger profit potential. On the other hand, bigger banks have better access to capital as showed by the positive correlation between debt and assets.

International Journal of Management and Applied Research, 2019, Vol. 6, No. 4 
Table 5: Pearson Correlation Matrix

\begin{tabular}{lcc}
\hline Variable & Islamic bank & Total Assets \\
\hline Islamic bank (1 if Islamic bank and 0 otherwise) & 1 & \\
Total Assets & $-0.4221^{* *}$ & 1 \\
Return on Equity & $-0.3026^{*}$ & $0.4326^{* *}$ \\
Return on Assets & $-0.4589^{* *}$ & -0.0079 \\
Earnings per Share & $-0.4683^{* *}$ & 0.0139 \\
Debt Ratio & $0.3430^{*}$ & $0.2970^{*}$ \\
\hline
\end{tabular}

Note: $* * *$ significant at $5 \%$ and $1 \%$, respectively

\section{Conclusion}

The objective of this paper is to assess the claim of some previous studies that IBs perform better than CBs. In order to examine this, the study analysed four IBs and CBs in the period from 2012 to 2016. Inconsistent with some previous studies, the results revealed that profitability (ROE, ROA and EPS) of CBs was higher than IBs. In addition, the capital structure of IBs was majorly composed of liabilities (debt ratio). These conclusions are the same for both t-test and Pearson correlation test.

Therefore, the paper provided contrary evidence to the expectations of some previous studies which claimed that IBs perform better than CBs (e.g. Hasan and Dridi, 2011; Khan et al., 2017). The contradictory findings are partly due to differences in sample periods, research design and sample populations (Boo et al., 2017). Although this study found that CBs outperformed IBs after the financial crisis, there are several studies that assert the relative stability of IBs amid the global financial crisis. Moreover, it can be argued that IBs have higher costs compared to their conventional counterparts, including Shariah board costs, Shariah screening methodology, Shariah governance and transaction costs (Islamic Financial Service Board, 2018). For instance, Tawarruq contracts involve many parties and various processes thus increasing operation costs for IBs compared to CBs (Ahmad et al., 2017). On the other hand, CBs earn more income than Islamic banks by charging interest (riba) on loans and impose a penalty fee in the case of late payment. However, IBs are not allowed to charge interest by lending to customers because it contradicts Shariah teaching (Muneeza et al., 2018). Furthermore, the profitability of IBs relies more on dynamics than that of conventional ones (Yanikkaya et al., 2018). The inclusion of these arguments in future studies may provide more insightful understanding of the issue.

Like conventional banks, Islamic banks also adopted Fintech in their businesses (Muneeza et al., 2018). For instance, in 2016, six Malaysian IBs including Bank Islam and Bank Muamalat have launched an Investment Account Platform (IAP), Malaysia's first multi-bank platform for financial intermediation in the Islamic financial system (Global Islamic Finance report, 2017). Investment in Fintech is likely to increase in the medium to long-term, which adds to operational expenditure (Islamic Financial Service Board, 2018). Fintech penetration in Islamic finance is still in its infancy stage; a matter which the Islamic financial institution including IBs in Malaysia should improve for better competitiveness (Global Islamic Finance report, 2017).

International Journal of Management and Applied Research, 2019, Vol. 6, No. 4 
There are some limitations of this research that should be addressed by future research. First, the paper studied only eight banks in Malaysia, a matter that may restrict its generalizability. Therefore, future research should be extended to bigger sample sizes and other countries. Second, the paper only used four performance indicators and further research should use additional measures to widen the scope. Third, this research only looked at fully-fledged IBs. However, the CBs chosen also provide Islamic banking services. Therefore, to make this conclusion more generalizable, future research may compare conventional and Islamic branches of the same bank. Fourth, two foreign IBs were included in the analysis. However, these two foreign IBs may have different characteristics from domestic banks.

\section{References}

1. Abdullah, F., Hassan, T. and Mohamad, S. (2007), "Investigation of performance of Malaysian Islamic unit trust funds", Managerial Finance, Vol. 33 No. 2, pp. 142-153. https://doi.org/10.1108/03074350710715854

2. Ahmad, A. U. F. and Hassan, M. K. (2007), "Regulation and performance of Islamic banking in Bangladesh", Thunderbird International Business Review, Vol. 49, No. 2, pp. 251-277. https://doi.org/10.1002/tie.20142

3. Ahmad, E. F.; Shihama, M.; Mohamad Tarmizi, N. A.; Jibril, S. M.; Djama, S. I. and Muneeza, A. (2017), "Tawarruq as a Product for Financing within the Islamic Banking System: A Case Study of Malaysian Islamic Banking System", International Journal of Management and Applied Research, Vol. 4, No. 1, pp. 3143. https://doi.org/10.18646/2056.41.17-004

4. Alam N.; Tang K.B. and Rajjaque M.S. (2016), "A Comparative Performance of Conventional and Islamic Unit Trusts: Market Timing and Persistence Evidence", In: Harrison T., Ibrahim E. (eds) Islamic Finance, Cham: Palgrave Macmillan, pp. 105-121. https://doi.org/10.1007/978-3-319-30918-7_7

5. Amin, H. (2012), "Patronage factors of Malaysian local customers toward Islamic credit cards", Management Research Review, Vol. 35, No. 6, pp. 512-530. https://doi.org/10.1108/01409171211238271

6. Bourkhis, K. and Nabi, M. S. (2013), "Islamic and conventional banks' soundness during the 2007-2008 financial crisis", Review of Financial Economics, Vol. 22, No. 2, pp. 68-77.

7. Boo, Y. L.; Ee, M. S.; Li, B. and Rashid, M. (2017), "Islamic or conventional mutual funds: Who has the upper hand? Evidence from Malaysia", Pacific-Basin Finance Journal, Vol. 42, $\quad$ pp. $183-192$. https://doi.org/10.1016/j.pacfin.2016.01.004

8. Chapra, M. U. (2011), “The global financial crisis: can Islamic finance help?”, In: Langton J., Trullols C., Turkistani A.Q. (Eds), Islamic Economics and Finance. London: Palgrave Macmillan. pp. 135-142. https://doi.org/10.1057/9780230361133_5

International Journal of Management and Applied Research, 2019, Vol. 6, No. 4 
9. Chen, N. ; Liang, H.Y. and Yu, M. T. (2018), "Asset diversification and bank performance: Evidence from three Asian countries with a dual banking system", Pacific-Basin Finance Journal, Vol. 52, pp. 40-53.

https://doi.org/10.1016/j.pacfin.2018.02.007

10. Global Islamic Finance Report (GIFR) (2017), Islamic Finance in the Digital Age: Fintech Revolution [Online] Available from http://www.gifr.net/gifr2017/ch_17.pdf [Accessed on 15 July 2019].

11. Hasan, M. M. and Dridi, J. (2011), "The effects of the global crisis on Islamic and conventional banks: A comparative study", Journal of International Commerce, Economics and Policy, Vol. 2, No. 2, pp. 163-200 https://doi.org/10.1142/S1793993311000270

12. Ibrahim, M. H. and Rizvi, S. A. R. (2018), "Bank lending, deposits and risk-taking in times of crisis: A panel analysis of Islamic and conventional banks", Emerging Markets Review, Vol. 35, pp. 31-47. https://doi.org/10.1016/j.ememar.2017.12.003

13. Islamic Financial Services Board (2018), Islamic Financial Services Industry Stability Report 2018 [Online] Available from: https://www.ifsb.org/download.php?id=4811\&lang=English\&pg=/index.php [Accessed on 15 July 2019].

14. Ivashina, V. and Scharfstein, D. (2010), "Bank lending during the financial crisis of 2008", Journal of Financial economics, Vol. 97, No. 3, pp. 319-338. https://doi.org/10.1016/j.jfineco.2009.12.001

15. Jawadi, F.; Jawadi, N. and Louhichi, W. (2014), "Conventional and Islamic stock price performance: An empirical investigation", International Economics, Vol. 137, pp. 73-87. https://doi.org/10.1016/j.inteco.2013.11.002

16. Kassim, S. and Majid, M. S. A. (2010), "Impact of financial shocks on Islamic banks", International Journal of Islamic and Middle Eastern Finance and Management, $\quad$ Vol. 3 No. 4, pp. 291-305. https://doi.org/10.1108/17538391011093243

17. Kayed, R. N. and Hassan, M. K. (2011), "The global financial crisis and Islamic finance", Thunderbird International Business Review, Vol. 53, No. 5, pp. 551-564. https://doi.org/10.1002/tie.20434

18. Khan, I., Khan, M. and Tahir, M. (2017), "Performance comparison of Islamic and conventional banks: empirical evidence from Pakistan", International Journal of Islamic and Middle Eastern Finance and Management, Vol. 10 No. 3, pp. 419-433. https://doi.org/10.1108/IMEFM-05-2016-0077

19. Muneeza, A.; Arshad, N. A. and Arifin, A. T. (2018), "The Application of Blockchain Technology in Crowdfunding: Towards Financial Inclusion via Technology ", International Journal of Management and Applied Research, Vol. 5, No. 2, pp. 82-98. https://doi.org/10.18646/2056.52.18-007

20. Samad, A. (2004), "Performance of Interest-free Islamic banks vis-à-vis Interestbased Conventional Banks of Bahrain", International Journal of Economics, Management and Accounting, Vol. 12, No. 2, pp. 1-15.

International Journal of Management and Applied Research, 2019, Vol. 6, No. 4 
Financial Performance of Islamic and Conventional Banks in Malaysia: A Comparative Analysis

21. Wasiuzzaman, S. and Gunasegavan, N. U. (2013), "Comparative study of the performance of Islamic and conventional banks: The case of Malaysia”, Humanomics, Vol. $29, \quad$ No. $\quad 1, \quad$ pp. $\quad 43-60$. https://doi.org/10.1108/08288661311299312

22. Yanikkaya, H.; Gumus, N. and Pabuccu, Y.U. (2018), "How profitability differs between conventional and Islamic banks: A dynamic panel data approach", Pacific-Basin Finance Journal, Vol. 48, pp. 99-111. https://doi.org/10.1016/j.pacfin.2018.01.006

International Journal of Management and Applied Research, 2019, Vol. 6, No. 4 